\title{
Menata Relasi Dewan Perwakilan Daerah Dan Kementerian Dalam Negeri Dalam Pengawasan Peraturan Daerah
}

\author{
Eka N A M Sihombing*
}

\begin{abstract}
Abstrak
Ketentuan Pasal 249 Undang-Undang Nomor 2 Tahun 2018 tentang Perubahan Kedua atas Undang-Undang Nomor 17 Tahun 2014 tentang Majelis Permusyawaratan Rakyat, Dewan Perwakilan Rakyat, Dewan Perwakilan Daerah, dan Dewan Perwakilan Rakyat Daerah memberikan wewenang dan tugas kepada DPD untuk melakukan pemantauan dan evaluasi atas Rancangan Peraturan Daerah dan Peraturan Daerah. Kewenangan DPD dapat menghadirkan rivalitas kewenangan pengawasan Peraturan Daerah dan berpotensi menimbulkan tumpang tindih kewenangan dengan Kementerian Dalam Negeri. Rumusan masalahan dalam penelitian ini bagaimana relasi antara DPD dengan Pemerintah Daerah dalam mengawasi jalannya suatu peraturan daerah?Tujuan penelitian untuk menganalisia relasi antara DPD dengan Pemerintah Daerah dalam mengawasi jalannya suatu peraturan daerah. Kegunaan dapat menambah khasanah keilmuan. Metode penelitian deskriptif normatif. Hasil penelitian yaitu kewenangan DPD dalam pengawasan terhadap pelaksanaan otonomi daerah sebagaimana amanah UUDNRI Tahun 1945 seharusnya dilakukan dalam bentuk pengawasan terhadap aktifitas pelaksanaan kewenangan pembinaan baik fasilitasi maupun evaluasi Ranperda yang dilakukan oleh Kemendagri/ Gubernur; dan dapat diwujudkan melalui fasilitasi penyelesaian permasalahan dalam pembentukan perda baik antara Pemerintah Daerah dengan Pemerintah Daerah maupun antara Pemerintah Daerah dengan Pemerintah Pusat dalam hal ini Kemendagri. Kesimpulan harus adanya keseimbangan antara kedua Lembaga tersebut dan berkesinambungan dalam mengawasi suatu peraturan serta memfasilitasi satu sama lain, sehingga tercipta suatu keharmonisan antar kedua Lembaga.
\end{abstract}

Kata Kunci: DPD, Kementerian Dalam Negeri, Peraturan Daerah

\section{Arranging Relations of the Regional Representatives Council and the Ministry of Home Affairs in Supervising Regional Regulations}

\begin{abstract}
The provisions of Article 249 of Law Number 2 of 2018 concerning the Second Amendment to Law Number 17 of 2014 concerning the People's Consultative Assembly, the House of Representatives, the Regional House of Representatives, and the Regional House of Representatives give the authority and duties to the DPD to carry out monitoring and evaluation of the Draft Regional Regulation and Regional Regulation. The authority of the Regional Representative Council can present rivalry over regional
\end{abstract}

*E-mail: ekahombing@umsu.ac.id 
regulatory authority and potentially create overlapping authority with the Ministry of Home Affairs. The formulation of the problem in this study is how is the relationship between the DPD and the Regional Government in supervising the running of a regional regulation? The purpose of this research is to analyze the relationship between the DPD and the Regional Government in overseeing the running of a regional regulation. Usability can add to the treasury of science. Normative descriptive research method. The results of the research are the authority of the DPD in supervising the implementation of regional autonomy as mandated by the 1945 Constitution of the Republic of Indonesia should be carried out in the form of supervision of the implementation activities of the fostering authority both in the facilitation and evaluation of the Regional Regulation carried out by the Ministry of Home Affairs / the Governor; and can be realized through facilitating the resolution of problems in the formation of local regulations both between the Regional Government and the Regional Government and between the Regional Government and the Central Government in this case the Ministry of Home Affairs. Conclusion there must be a balance between the two Institutions and continuous in supervising a regulation and facilitating each other, so as to create a harmony between the two Institutions.

Keywords: DPD, Ministry of Home Affairs; By law

\section{Pendahuluan}

Ketentuan Undang-Undang Nomor 23 Tahun 2014 tentang Pemerintahan Daerah, memberikan kewenangan kepada Menteri Dalam Negeri dan Gubernur secara berjenjang melakukan pengawasan baik secara preventif maupun represif terhadap Peraturan Daerah maupun peraturan Kepala Daerah. Namun, pasca putusan Mahkamah Konstitusi Nomor 137/PUU-XIII/2015 dan Nomor 56/PUUXIV/2016 Menteri Dalam Negeri maupun Gubernur tidak lagi berwenang untuk membatalkan peraturan daerah. dalam putusannya Mahkamah Konstitusi terlihat berupaya untuk mendudukkan kembali kewenangan pengujian peraturan perundang-undangan di bawah undang-undang kepada Mahkamah Agung sebagaimana diamanahkan dalam ketentuan Pasal 24A UUD NRI 1945. Putusan tersebut juga tidak serta merta menghilangkan keseluruhan kewenangan Pengawasan Pemerintah dalam hal ini Menteri Dalam Negeri terhadap produk hukum daerah. Menteri Dalam Negeri masih memiliki kewenangan pengawasan preventif dengan melakukan evaluasi terhadap rancangan peraturan daerah yang diatur sesuai Undang-Undang di bidang pemerintahan daerah dan peraturan 
perundang undangan lainnya untuk mengetahui bertentangan dengan kepentingan umum, dan/atau peraturan perundang-undangan yang lebih tinggi.

Seiring berjalannya waktu, kewenangan pemantauan dan evaluasi terhadap peraturan daerah muncul kembali, namun kewenangan tersebut diberikan kepada Lembaga Dewan Perwakilan Daerah (DPD) melalui Undang-Undang Nomor 2 Tahun 2018 tentang Perubahan Kedua atas Undang-Undang Nomor 17 Tahun 2014 tentang Majelis Permusyawaratan Rakyat, Dewan Perwakilan Rakyat, Dewan Perwakilan Daerah, dan Dewan Perwakilan Rakyat Daerah (selanjutnya disebut UU Perubahan MD3). Ketentuan Pasal 249 UU Perubahan MD3 menyatakan bahwa salah satu wewenang dan tugas DPD adalah "melakukan pemantauan dan evaluasi atas rancangan peraturan daerah dan peraturan daerah".

Kewenangan DPD yang demikian khususnya evaluasi terhadap peraturan daerah tentunya dirasa aneh, dikarenakan disaat Mahkamah Konstitusi melalui putusannya berupaya mengembalikan ruh konstitusi dimana yang paling berwenang untuk melakukan pengujian terhadap peraturan perundang-undangan dibawah Undang-Undang khususnya Peraturan Daerah adalah kekuasaan kehakiman bukan kekuasaan legislatif maupun eksekutif, disaat itu pula hadir ketentuan Undang-Undang yang justru menghadirkan rivalitas kewenangan pengawasan Peraturan Daerah dan berpotensi menimbulkan tumpang tindih kewenangan antar kedua Lembaga tersebut.

Berdasarkan hal tersebut menarik untuk mengurai lebih lanjut kewenangan DPD maupun Kementerian Dalam Negeri dalam Pengawasan Perda dan mengurai relasi yang ideal antara DPD dan Kementerian Dalam Negeri dalam hal pengawasan peraturan Daerah. Adapun rumusan masalahnya adalah Bagaimana seharusnya relasi DPD dan Kementerian Dalam Negeri dalam pengawasan peraturan daerah? 


\section{Pembahasan}

\section{A. Kewenangan DPD dalam Pemantauan dan Evaluasi Rancangan Perda dan Perda}

Hadirnya lembaga perwakilan baru melalui amandemen UUD Tahun 1945 telah merubah struktur parlemen dalam ketatanegaraan Indonesia. Dalam amandemen tersebut melahirkan Dewan Perwakilan Daerah (DPD) sebagai perwakilan aspirasi kewilayahan di tingkat pusat. Secara historis, Muhammad Fajrul Falakh menyatakan bahwa kehadiran DPD merupakan perkembangan dari ide merepresentasikan suatu wilayah atau territorial yang pada akhirnya dipandang sebagai upaya institusionalisasi keterwakilan daerah dalam tipologi sistem parlemen Indonesia (Hartati:2018:173) Kehadiran Dewan Perwakilan Daerah sebagai salah satu pelaksana lembaga legislatif di Indonesia, pada awalnya dibentuk karena tiga alasan, yakni (i) memperkuat ikatan daerah-daerah dalam wadah Negara Kesatuan Republik Indonesia; (ii) meningkatkan agregasi dan akomodasi aspirasi dan kepentingan daerah-daerah dalam perumusan kebijakan nasional berkaitan dengan negara dan daerah-daerah; (iii) mendorong percepatan demokrasi pembangunan dan kemajuan daerah secara serasi dan seimbang (MPR RI:2003:180) Akan tetapi kenyataannya Dewan Perwakilan Daerah tidak memiliki kewenangan yang signifikan jika dibandingkan dengan kewenangan yang diberikan kepada Dewan Perwakilan Rakyat. Kewenangan Dewan Perwakilan Daerah sebagaimana diatur dalam Pasal 22D UndangUndang Dasar Negara Republik Indonesia Tahun 1945 sebagai berikut:

1. Dapat mengajukan kepada Dewan Perwakilan Rakyat rancangan undangundang yang berkaitan dengan otonomi daerah, hubungan pusat dan daerah, pembentukan dan pemekaran serta penggabungan daerah, pengelolaan sumber daya alam dan sumber daya ekonomi lainnya, serta yang berkaitan dengan perimbangan keuangan pusat dan daerah.

2. Ikut membahas rancangan undang-undang yang berkaitan dengan otonomi daerah; hubungan pusat dan daerah; pembentukan, pemekaran, dan penggabungan daerah; pengelolaan sumber daya alam dan sumber daya ekonomi lainnya, serta perimbangan keuangan pusat dan daerah; serta 
memberikan pertimbangan kepada Dewan Perwakilan Rakyat atas rancangan undang-undang anggaran pendapatan dan belanja negara dan rancangan undang-undang yang berkaitan dengan pajak, pendidikan, dan agama.

3. Melakukan pengawasan atas pelaksanaan undang-undang mengenai: otonomi daerah, pembentukan, pemekaran dan penggabungan daerah, hubungan pusat dan daerah, pengelolaan sumber daya alam dan sumber daya ekonomi lainnya, pelaksanaan anggaran pendapatan dan belanja negara, pajak, pendidikan, dan agama serta menyampaikan hasil pengawasannya itu kepada Dewan Perwakilan Rakyat sebagai bahan pertimbangan untuk ditindaklanjuti.

Melihat kewenangan Dewan Perwakilan Daerah yang demikian, Jimly Asshiddiqie bahkan menyatakan bahwa Dewan Perwakilan Daerah adalah colegislator bagi Dewan Perwakilan Rakyat. Peran Dewan Perwakilan Daerah dalam pembentukan undang-undang meliputi (1) sebagai inisiator atau pengusul rancangan undang-undang di bidang-bidang tertentu; (2) sebagai co-legislator dalam pembahasan rancangan undang-undang dibidang tertentu; dan (3) sebagai pemberi pertimbangan kepada Dewan Perwakilan Rakyat atas rancangan undang-undang tertentu (Jimly Assshiddiqie:2012:125)

Keberadaan DPD sebagai co-legislator masih mengalami pelemahan berdasarkan Undang-Undang Nomor 12 Tahun 2011 tentang Pembentukan Peraturan Perundang-undangan. Ketentuan tersebut kemudian diajukan pengujian ke Mahkamah Konstitusi oleh DPD. Dalam putusan Mahkamah Konstitusi tersebut, mahkamah menyimpulkan 5 (lima) pokok persoalan konsitusional, yaitu:(1) kewenangan DPD mengusulkan rancangan undangundang yang diatur dalam Pasal 22D Undang-Undang Dasar 1945 yang menurut DPD rancangan undang-undang DPD harus diperlakukan setara dengan rancangan undang-undang dari Presiden dan DPR; (2) kewenangan DPD ikut membahas rancangan undang-undang yang disebut Pasal 22D Undang-Undang Dasar 1945 bersama DPR dan Presiden; (3) kewenangan DPD memberi 
persetujuan atas rancangan undang-undang yang disebut Pasal 22D UndangUndang Dasar 1945; (4) keterlibatan DPD dalam program legislasi nasional yang menurut DPD sama dengan keterlibatan DPR dan Presiden, serta kewenangan DPD memberi pertimbangan terhadap rancangan undang-undang yang disebut Pasal 22 Undang-Undang Dasar 1945 (Eka.N.A.M Sihombing\&Ali Marwan: 2017:149).

Kemudian dalam putusan Mahkamah Konstitusi Nomor 92/PUU-X/2012, mahkamah menyatakan bahwa kedudukan DPD dalam bidang legislasi setara dengan Presiden dan DPR. Di mana DPD berhak mengajukan rancangan undang-undang dan rancangan tersebut menjadi rancangan inisiatif DPD. Kemudian DPD ikut dalam penyusunan perancanaan pembentukan undangundang dalam program legislasi nasional, selain itu DPD juga ikut membahas rancangan undang-undang bersama Presiden dan DPR. Di mana DPD ikut dalam 3 (tiga) tahapan dalam Pembicaraan Tingkat I, yaitu pengantar musyawarah, pembahasan daftar inventarisasi masalah dan penyampaian pendapat mini, sedangkan sebelumnya hanya ikut dalam 2 (dua) tahapan yaitu pengantar musyawarah dan penyampaian pendapat mini. Selanjutnya dalam Pembicaraan Tingkat II, DPD menyampaikan pendapat sebelum persetujuan DPR dan Presiden (Eka.N.A.M Sihombing\&Ali Marwan: 2017:150).

Amar putusan Mahkamah Konstitusi tersebut kemudian diakomodir dalam Undang-Undang Nomor 17 Tahun 2014 tentang Majelis Permusyawaratan Rakyat, Dewan Perwakilan Rakyat, Dewan Perwakilan Daerah, dan Dewan Perwakilan Rakyat Daerah. Akan tetapi, keanehan kembali terjadi terkait dengan wewenang dan tugas Dewan Perwakilan Daerah pasca diundangkannya Undang-Undang Nomor 2 Tahun 2018 tentang Perubahan Kedua atas UndangUndang Nomor 17 Tahun 2014 tentang Majelis Permusyawaratan Rakyat, Dewan Perwakilan Rakyat, Dewan Perwakilan Daerah, dan Dewan Perwakilan Rakyat Daerah. Dalam Pasal 249 disebutkan bahwa salah satu wewenang dan tugas DPD adalah "melakukan pemantauan dan evaluasi atas rancangan peraturan daerah dan peraturan daerah". Ketentuan tersebut mengandung makna bahwa DPD juga memiliki kewenangan pengawasan preventif maupun 
pengawasan represif (namun pengawasan represif yang dimiliki oleh DPD tidak executionable, karena hanya bersifat rekomendasi). Lebih lanjut kewenangan DPD dalam pemantauan dan evaluasi terhadap Perda tersebut diartikulasikan oleh Panitia Urusan Legislasi Daerah (PULD). Berdasarkan ketentuan Pasal 141 Peraturan DPD RI Nomor 2 Tahun 2019 Tentang Tata Tertib disebutkan bahwa dalam Pemantauan dan Evaluasi Ranperda dan Perda, PULD melakukan penelaahan, analisis, dan pengkajian terhadap temuan hasil pemantauan rancangan Perda dan Perda; dan melakukan pembahasan dan penyusunan rekomendasi DPD mengenai pemantauan dan evaluasi rancangan Perda dan Perda. Tugas yang demikian, khususnya terkait dengan pemantauan dan evaluasi ranperda pada prinsipnya juga dilakukan oleh Pemerintah dalam hal ini Menteri Dalam Negeri maupun Gubernur secara berjenjang melalui kegiatan evaluasi maupun fasilitasi. Sedangkan pengawasan terhadap Perda yang dimiliki oleh DPD, sebelum putusan MK Nomor 137/PUU-XIII/2015 dan Nomor 56/PUUXIV/2016 Pemerintah juga memiliki kewenangan melakukan pengawasan Perda yang diimplementasikan melalui Pembatalan. Pembatalan berdasarkan ketentuan Pasal 1 angka 27 Permendagri Nomor 80 Tahun 2015 merupakan tindakan yang menyatakan tidak berlakunya terhadap seluruh atau sebagian buku, bab, bagian, paragraf, pasal, ayat, dan/atau lampiran materi muatan perda, perkada, PB KDH dan peraturan DPRD karena bertentangan dengan peraturan perundangundangan yang lebih tinggi, kepentingan umum, dan/atau kesusilaan, yang berdampak dilakukannya pencabutan atau perubahan.

\section{B. Kewenangan Kemendagri dalam Pengawasan Peraturan Daerah \\ 1. Pra Putusan MK Nomor 137/PUU-XIII/2015 dan Nomor 56/PUU- XIV/2016}

Sebelum putusan MK Nomor 137/PUU-XIII/2015 dan Nomor 56/PUUXIV/2016, Kementerian Dalam Negeri melalui ketentuan UU Nomor 23 Tahun 2014 tentang Pemerintahan Daerah diberikan kewenangan untuk melakukan pengawasan baik secara preventif maupun represif terhadap produk hukum daerah. Implementasi Pengawasan Preventif dan represif terhadap produk 
hukum daerah tersebut dapat dilihat dalam ketentuan UU Nomor 23 Tahun 2014 maupun Peraturan Menteri Dalam Negeri Nomor 80 Tahun 2015 tentang Pembentukan Produk Hukum Daerah (Eka.N.A.M.Sihimbing:Jurnal Yudisial:2017:217-234).

\section{a. Pembinaan Rancangan Peraturan Daerah}

Pembinaan terhadap rancangan Peraturan daerah berbentuk provinsi dilakukan oleh Menteri Dalam Negeri melalui Direktur Jenderal Otonomi Daerah. Adapun pembinaan terhadap rancangan peraturan daerah kabupaten/kota dilakukan oleh Gubernur.

Pembinaan dilakukan fasilitasi terhadap rancangan peraturan daerah sebelum mendapat persetujuan bersama antara pemerintah daerah dengan DPRD. Fasilitasi terhadap rancangan peraturan daerah tidak diberlakukan terhadap rancangan peraturan daerah yang dilakukan evaluasi. Rancangan peraturan daerah disampaikan kepada Menteri Dalam Negeri melalui Direktur Jenderal Otonomi Daerah bagi provinsi dan Gubernur bagi kabupaten/kota.

Fasilitasi yang dilakukan oleh Menteri Dalam Negeri melalui Direktur Jenderal Otonomi Daerah bagi provinsi dan Gubernur bagi kabupaten/kota dilakukan paling lama 15 (lima belas) hari setelah diterima rancangan peraturan daerah. Apabila dalam tenggang waktu dimaksud Menteri Dalam Negeri melalui Direktur Jenderal Otonomi Daerah bagi provinsi dan Gubernur bagi kabupaten/kota tidak memberikan fasilitasi, maka terhadap rancangan peraturan daerah dilanjutkan tahapan persetujuan bersama antara Kepala Daerah dan DPRD. Fasilitasi untuk provinsi dibuat dalam bentuk surat Direktur Jenderal Otonomi Daerah atas nama Menteri Dalam Negeri tentang fasilitasi rancangan peraturan daerah provinsi, sedngkan fasilitasi untuk kabupaten/kota dibuat dalam bentuk surat sekretaris daerah atas nama Gubernur tentang fasilitasi rancangan peraturan daerah kabupaten/kota. Surat dimaksud ditindaklanjuti oleh pemerintah daerah untuk penyempurnaan rancangan peraturan daerah sebelum ditetapkan guna 
menghindari dilakukannya pembatalan.(Eka.N.A.M.Sihombing:Jurnal Yudisial:2017:217-234).

\section{b. Evaluasi Rancangan Peraturan daerah}

Berdasarkan ketentuan Permendagri Nomor 80 Tahun 2015, Menteri Dalam Negeri melakukan evaluasi rancangan peraturan daerah provinsi dan Gubernur melakukan evaluasi rancangan peraturan daerah kabupaten/kota sesuai dengan:

1). undang-undang di bidang pemerintahan daerah; dan

2). peraturan perundang-undangan lainnya.

Evaluasi rancangan peraturan daerah sesuai dengan Undang-Undang di bidang pemerintahan daerah, terdiri atas:

1) RPJPD;

2) RPJMD;

3) APBD, perubahan APBD, pertanggungjawaban pelaksanaan APBD;

4) pajak daerah;

5) retribusi daerah; dan

6) tata ruang daerah.

Evaluasi rancangan peraturan daerah sesuai peraturan perundangundangan lainnya antara lain:

1) rencana pembangunan industri; dan

2) pembentukan, penghapusan, penggabungan, dan/atau perubahan status Desa menjadi kelurahan atau kelurahan menjadi Desa.

\section{c. Evaluasi Rancangan Peraturan daerah Provinsi}

Rancangan peraturan daerah provinsi yang mengatur tentang APBD, perubahan APBD, pertanggungjawaban pelaksanaan APBD, pajak daerah, retribusi daerah, dan rancangan peraturan Gubernur tentang penjabaran APBD yang telah disetujui bersama sebelum ditetapkan oleh Gubernur paling lama 3 (tiga) hari disampaikan kepada Menteri Dalam Negeri melalui Sekretaris Jenderal. Rancangan peraturan daerah dimaksud disampaikan Sekretaris Jenderal paling lama 3 (tiga) hari kepada Direktur 
Jenderal Bina Keuangan Daerah untuk dievaluasi. Rancangan peraturan daerah provinsi yang mengatur tentang RPJPD, RPJMD, tata ruang daerah dan rencana pembangunan industri provinsi yang telah disetujui bersama sebelum ditetapkan oleh Gubernur paling lama 3 (tiga) hari disampaikan kepada Menteri Dalam Negeri melalui Sekretaris Jenderal. Rancangan peraturan daerah dimaksud disampaikan Sekretaris Jenderal paling lama 3 (tiga) hari kepada Direktur Jenderal Bina Pembangunan Daerah untuk dievaluasi.

Rancangan peraturan daerah provinsi harus mendapat evaluasi Menteri Dalam Negeri sebelum ditetapkan oleh Gubernur. Menteri Dalam Negeri dalam melakukan evaluasi yaitu:

1) melalui Direktur Jenderal Bina Keuangan Daerah terhadap rancangan peraturan daerah provinsi tentang pajak daerah dan retribusi daerah dan berkoordinasi dengan menteri yang menyelenggarakan urusan pemerintahan bidang keuangan;

2) melalui Direktur Jenderal Bina Pembangunan Daerah terhadap rancangan peraturan daerah provinsi tentang tata ruang daerah dan berkoordinasi dengan menteri yang menyelenggarakan urusan pemerintahan dibidang tata ruang;

3) melalui Direktur Jenderal Bina Pembangunan Daerah terhadap rancangan peraturan daerah provinsi tentang rencana pembangunan industri dan berkoordinasi dengan menteri yang menyelenggarakan urusan pemerintahan dibidang perindustrian.

Evaluasi terhadap rancangan peraturan daerah provinsi tersebut diatas ditetapkan dengan Keputusan Menteri Dalam Negeri tentang evaluasi. Keputusan Menteri Dalam Negeri tentang evaluasi diharmonisasikan dan dicetak pada kertas bertanda khusus oleh Biro Hukum Kementerian Dalam Negeri. Permohonan pengharmonisasian evaluasi dilakukan dengan menyampaikan:

1) surat permohonan harmonisasi;

2) rancangan peraturan daerah disertai softcopy dalam bentuk pdf; dan 
3) rancangan Keputusan Menteri Dalam Negeri tentang evaluasi disertai softcopy.

Dalam rangka pengharmonisasian dibentuk tim harmonisasi evaluasi terhadap rancangan peraturan daerah provinsi pada Sekretariat Jenderal Kementerian Dalam Negeri.

\section{d. Evaluasi Rancangan Peraturan Daerah Kabupaten/Kota}

Bupati/Walikota menyampaikan rancangan peraturan daerah kabupaten/ kota kepada Gubernur paling lama 3 (tiga) hari sebelum ditetapkan oleh Bupati/ Walikota yang mengatur tentang:

1) RPJPD;

2) RPJMD;

3) APBD, perubahan APBD, pertanggungjawaban pelaksanaan APBD;

4) pajak daerah;

5) retribusi daerah;

6) tata ruang daerah;

7) rencana pembangunan industri kabupaten/kota; dan

8) pembentukan, penghapusan, penggabungan, dan/atau perubahan status Desa menjadi kelurahan atau kelurahan menjadi Desa.

Bupati/Walikota menyampaikan rancangan peraturan Bupati/Walikota tentang penjabaran APBD kepada Gubernur paling lama 3 (tiga) hari sebelum ditetapkan oleh Bupati/Walikota. Rancangan peraturan daerah kabupaten/kota harus mendapat evaluasi Gubernur sebagai wakil Pemerintah Pusat sebelum ditetapkan oleh Bupati/Walikota.

Gubernur sebagai wakil Pemerintah Pusat dalam melakukan evaluasi rancangan peraturan daerah kabupaten/kota tentang:

1) pajak daerah dan retribusi daerah berkonsultasi dengan Menteri Dalam Negeri melalui Direktur Jenderal Bina Keuangan Daerah dan selanjutnya Menteri Dalam Negeri berkoordinasi dengan menteri yang menyelenggarakan urusan pemerintahan bidang keuangan; dan 
2) tata ruang daerah berkonsultasi dengan Menteri Dalam Negeri melalui Direktur Jenderal Bina Pembangunan Daerah dan selanjutnya Menteri Dalam Negeri berkoordinasi dengan menteri yang menyelenggarakan urusan pemerintahan bidang tata ruang.

Konsultasi Gubernur sebagai wakil Pemerintah Pusat kepada Menteri Dalam Negeri dalam bentuk penyampaian keputusan Gubernur tentang evaluasi rancangan peraturan daerah kabupaten/kota untuk dilakukan pengkajian. Konsultasi rancangan peraturan daerah dimaksud ke Kementerian Dalam Negeri dikoordinasikan oleh perangkat daerah yang membidangi hukum provinsi.

\section{Pembatalan Perda}

Pengaturan mengenai pembatalan peraturan daerah dan peraturan kepala daerah dapat ditemui dalam rumusan ketentuan Bab IX Bagian Ketiga Pasal 249-252 Undang-Undang Nomor 23 Tahun 2014, dalam ketentuan tersebut dinyatakan bahwa peraturan daerah maupun peraturan kepala daerah dilarang bertentangan dengan ketentuan peraturan perundang-undangan yang lebih tinggi, kepentingan umum, dan/atau kesusilaan. Apabila peraturan daerah maupun peraturan kepala daerah bertentangan dengan ketentuan dimaksud, maka gubernur sebagai wakil pemerintah pusat dapat membatalkan peraturan daerah atau peraturan kepala daerah kabupaten/kota, dan Menteri Dalam Negeri dapat membatalkan peraturan daerah atau peraturan kepala daerah provinsi.

Selanjutnya dalam ketentuan Bab XI Peraturan Menteri Dalam Negeri Nomor 80 Tahun 2015 tentang Pembentukan Produk Hukum Daerah disebutkan bahwa dalam hal peraturan daerah provinsi atau peraturan gubernur setelah ditetapkan, dalam jangka waktu tujuh hari setelah ditetapkan harus disampaikan kepada Menteri.

Direktur Jenderal Otonomi Daerah atas nama Menteri Dalam Negeri membentuk tim pembatalan peraturan daerah provinsi dan peraturan gubernur yang anggotanya terdiri atas komponen lingkup Kementerian Dalam Negeri dan Kementerian terkait sesuai kebutuhan. 
Hasil kajian tim pembatalan peraturan daerah atau peraturan kepala daerah dapat berupa pernyataan tidak bertentangan dengan peraturan perundangundangan yang lebih tinggi, kepentingan umum, dan/atau kesusilaan dan dapat pula berupa pernyataan bertentangan peraturan perundang-undangan yang lebih tinggi, kepentingan umum, dan/atau kesusilaan.

Permendagri Nomor 80 Tahun 2015 ini juga mengatur mengenai instrumen pembatalan peraturan daerah dan peraturan kepala daerah melalui Keputusan Gubernur atau Keputusan Menteri. Pembatalan peraturan daerah dan peraturan kepala daerah melalui instrumen Keputusan Gubernur atau Keputusan Menteri patut dianggap bertentangan dengan rezim peraturan perundang-undangan yang ada di Indonesia, hal ini sejalan dengan yang diuraikan oleh Ni'matul Huda yang menyatakan karena peraturan daerah itu termasuk kategori peraturan yang berdasarkan hierarki peraturan perundang-undangan berada di bawah undangundang, maka dapat timbul penafsiran bahwa pemerintah pusat sudah seharusnya tidak diberikan kewenangan oleh undang-undang untuk menilai dan mencabut peraturan daerah sebagaimana diatur oleh Undang-Undang Pemerintahan Daerah (Ni’matul Huda:Jurnal Konstitusi:2008:45-62).

\section{Pasca Putusan MK}

Telah diuraikan terdahulu, bahwa dalam Putusan Nomor 137/PUUXIII/2015 menyatakan bahwa frase "peraturan daerah kabupaten/ kota dan" dalam ketentuan Pasal 251 ayat (2) dan (4), frase "peraturan daerah kabupaten/ kota dan/atau" dalam Pasal 251 ayat (3), dan frase "penyelenggara pemerintahan daerah kabupaten/kota tidak dapat menerima keputusan pembatalan peraturan daerah kabupaten/kota dan” Undang-Undang Nomor 23 Tahun 2014 tentang Pemerintahan Daerah bertentangan dengan UUD NRI 1945 dan tidak mempunyai kekuatan hukum mengikat. Dengan demikian baik Menteri Dalam Negeri maupun gubernur tidak lagi berwenang membatalkan peraturan daerah kabupaten/kota.

Pembatalan peraturan daerah harus dilakukan melalui mekanisme judicial review di Mahkamah Agung. Setelah Putusan Nomor 137/ PUU-XIII/2015, 
Mahkamah Konstitusi pada tanggal 14 Juni 2017 juga mengeluarkan Putusan Nomor 56/PUU-XIV/2016 tentang Pengujian atas Undang-Undang Nomor 23 Tahun 2014 tentang Pemerintahan Daerah. Para pemohon dalam perkara ini kembali mempermasalahkan konstitusionalitas dari ketentuan mengenai pembatalan peraturan daerah baik peraturan daerah provinsi maupun peraturan daerah kabupaten/kota yang diatur di dalam Pasal 251 ayat (1) dan (2) UndangUndang Nomor 23 Tahun 2014 tentang Pemerintahan Daerah.

Putusan Nomor 56/PUU-XIV/2016 ini sekaligus melengkapi Putusan Nomor 137/PUUXIII/2015, sehingga pemerintah pusat tidak lagi memiliki kewenangan untuk melakukan pembatalan peraturan daerah baik peraturan daerah provinsi maupun peraturan daerah kabupaten/kota. Sekilas, putusan ini telah mengembalikan ruh kewenangan pembatalan peraturan perundangundangan di bawah undang-undang kepada Mahkamah Agung sebagaimana dicantumkan secara eksplisit dalam ketentuan Pasal 24A UUD NRI 1945. Akan tetapi apabila ditelaah secara mendalam, maka putusan ini justru tidak sepenuhnya mengembalikan kewenangan pembatalan peraturan perundangundangan di bawah undang-undang kepada Mahkamah Agung.

Hal ini dikarenakan putusan Mahkamah Konstitusi hanya berlaku terhadap peraturan daerah provinsi dan peraturan daerah kabupaten/ kota, sedangkan terhadap peraturan kepala daerah (peraturan gubernur serta peraturan bupati/ wali kota) masih tetap dapat dibatalkan oleh Menteri Dalam Negeri maupun gubernur secara berjenjang. Dan bahkan antara pertimbangan dengan putusan dapat dikatakan inkonsisten. Dalam pertimbangan Putusan Nomor 137/PUUXIII/2015 dinyatakan: “... bahwa pembatalan peraturan daerah kabupaten/kota melalui keputusan gubernur sebagaimana dimaksud dalam Pasal 251 ayat (4) Undang-Undang Pemerintah Daerah, menurut Mahkamah Konstitusi tidak sesuai dengan rezim peraturan perundang-undangan yang dianut. Pasal 7 ayat (1) dan Pasal 8 ayat (2) tidak mengenal keputusan gubernur sebagai salah satu jenis hierarki peraturan perundangundangan maupun Keputusan Menteri sebagai peraturan perundang-undangan. Dengan demikian kedudukan keputusan gubernur bukanlah bagian dari rezim peraturan 
perundang-undangan, sehingga tidak dapat dijadikan produk hukum untuk membatalkan peraturan daerah kabupaten/kota. Lebih lanjut dalam Putusan Nomor 56/ PUU-XIV/2016 dengan mendasarkan pada pertimbangan hukum dalam Putusan Nomor 137/PUU-XIII/2015 yang menyatakan bahwa pembatalan peraturan daerah kabupaten/kota melalui executive review adalah bertentangan dengan UUD NRI 1945. Oleh karena dalam Pasal 251 ayat (1) Undang-Undang Nomor 23 Tahun 2014 tentang Pemerintahan Daerah mengatur mengenai pembatalan peraturan daerah provinsi juga melalui executive review maka pertimbangan hukum dalam Putusan Nomor 137/PUU-XIII/2015 berlaku pula pada Putusan Nomor 56/PUU-XIV/2016, sehingga Mahkamah Konstitusi berpendapat bahwa Pasal 251 ayat (1) Undang-Undang Nomor 23 Tahun 2014 tentang Pemerintahan Daerah sepanjang frasa "peraturan daerah provinsi dan" bertentangan dengan UUD NRI 1945.

Mahkamah Konsitusi dalam putusannya, tidak menyatakan bahwa frase “... dan peraturan gubernur ...” dan frase “... peraturan bupati/ wali kota sebagaimana dimaksud pada ayat (2) ditetapkan dengan keputusan gubernur sebagai wakil pemerintah pusat" dalam ketentuan Pasal 251 ayat (4) UndangUndang Nomor 23 Tahun 2014 tidak memiliki kekuatan mengikat.

Selain itu Mahkamah Konstitusi seharusnya juga memutus bahwa frase “... dan peraturan gubernur" dan “... dan peraturan bupati/wali kota” sebagaimana dimaksud dalam ketentuan Pasal 251 ayat (1) dan (2), serta frase "penyelenggara pemerintahan daerah provinsi tidak dapat menerima keputusan pembatalan peraturan daerah provinsi dan peraturan gubernur" dan frase "penyelenggara pemerintahan daerah kabupaten/kota tidak dapat menerima keputusan pembatalan peraturan daerah kabupaten/kota dan peraturan bupati/ wali kota" sebagaimana dimaksud pada ayat (7) dan (8) Undang-Undang Pemerintah Daerah bertentangan dengan UUD NRI 1945 dan tidak mempunyai kekuatan hukum mengikat.

Mengingat proses pembentukan suatu produk hukum daerah membutuhkan waktu, biaya, dan tenaga yang tidak sedikit. Sehingga jauh lebih efektif dan efisien apabila pengujian dilakukan oleh pemerintah pada saat sebelum produk 
hukum daerah tersebut diundangkan. Hal ini sejalan dengan ruh ketentuan Pasal 24A UUD NRI 1945 yang sama sekali tidak memberikan delegasi kewenangan pengujian terhadap peraturan daerah maupun peraturan kepala daerah kepada lembaga eksekutif.

\section{E. Rekontruksi Relasi DPD dan Mendagri}

Meskipun alasan kehadiran kewenangan tersebut bertolak dari ketentuan Pasal 22D UUDNRI Tahun 1945 yang menyatakan bahwa DPD berwenang melakukan pengawasan terhadap pelaksanaan otonomi daerah, (Enny Nurbaningsih:2019:345) yang kemudian diwujudkan dalam ketentuan UU Nomor 2 Tahun 2018 dengan memberikan kewenangan kepada DPD untuk melakukan pemantauan dan evaluasi terhadap rancangan Perda maupun perda. Namun, apabila dicermati kewenangan pengawasan terhadap perda yang dimiliki oleh DPD maupun Kemendagri, dalam praktiknya bisa saja berpotensi menimbulkan rivalitas antar Lembaga. Hal ini dikarenakan 3 (tiga) hal sebagai berikut;

Pertama, dalam ketentuan UUDNRI Tahun 1945 menyatakan secara tegas, bahwa yang diberikan kewenangan untuk melakukan pengujian materil terhadap peraturan perundang-undangan hanya oleh kekuasaan kehakiman. Dengan demikian, sudah sepatutnya pengujian terhadap peraturan perundang-undangan tidak diberikan kepada Lembaga selain pemangku kekuasaan kehakiman.

Kedua, kewenangan "evaluasi” yang dimiliki oleh kedua Lembaga tersebut menimbulkan contradictio in terminis. Dimana terdapat dua pengertian terhadap kewenangan evaluasi. Dalam UU Pemerintahan Daerah "evaluasi” merupakan salah satu wujud pengawasan terhadap perda tertentu sebelum diundangkan (preventif), sedangkan dalam UU Perubahan Kedua MD3 “evaluasi” merupakan salah satu wujud pengawasan terhadap rancangan perda (preventif) maupun perda (represif).

Ketiga, potensi duplikasi objek pengawasan dapat saja terjadi, misal : satu ranperda kabupaten/kota maupun ranperda Provinsi yang telah dilakukan evaluasi oleh Gubernur ataupun Mendagri, dan hasil evaluasi tersebut 
dinyatakan telah sesuai dengan ketentuan peraturan perundang-undangan bisa saja DPD berpendapat sebaliknya. Hal ini tentunya akan membuat daerah bertambah sulit untuk menetapkan perda (terutama perda-perda yang dibutuhkan untuk mengakselerasi pembangunan di daerah). Bagaimana tidak, untuk menetapkan suatu perda sebelum disetujui bersama antara Kepala Daerah dengan diundangkan, harus terlebih dahulu mendapatkan fasilitasi berupa tindakan pembinaan berupa pemberian pedoman dan petunjuk teknis, arahan, bimbingan teknis, supervisi, asistensi dan kerja sama serta monitoring dan evaluasi yang dilakukan oleh Menteri Dalam Negeri kepada provinsi serta Menteri Dalam Negeri dan/atau gubernur kepada kabupaten/kota terhadap materi muatan rancangan produk hukum daerah berbentuk peraturan sebelum ditetapkan guna menghindari dilakukannya pembatalan.

Kewenangan DPD melakukan pengawasan terhadap pelaksanaan otonomi daerah sebagaimana ditentukan dalam UUD NRI Tahun 1945 seharusnya tidak dimaknai dengan DPD sebagai eksekutor pemantauan dan evaluasi terhadap Perda yang justru menjauhkan salah satu tujuan awal pembentukan DPD itu sendiri yaitu meningkatkan agregasi dan akomodasi aspirasi dan kepentingan daerah-daerah dalam perumusan kebijakan nasional berkaitan dengan negara dan daerah-daerah. Untuk menyelesaikan berbagai persoalan perda bermasalah, seharusnya DPD menghadirkan solusi berupa rekomendasi yang komprehensif untuk perumusan kebijakan nasional. Karena akar sengkarut perda bermasalah tidak hanya terletak pada materi perda, akan tetapi peraturan perundangundangan tingkat nasional yang tumpang tindih juga berkontribusi melahirkan perda-perda bermasalah.

Untuk mengatasi rivalitas kewenangan pengawasan perda, perlu dilakukan penataan relasi antara DPD dengan Pemerintah dalam hal ini Kemendagri/ Gubernur, dengan mengembalikan ruh pengujian terhadap perda kepada kekuasaan kehakiman dalam hal ini Mahkamah Agung. Selain itu, kewenangan DPD dalam pengawasan terhadap pelaksanaan otonomi daerah dapat diwujudkan melalui pengawasan terhadap aktifitas pelakanaan kewenangan pembinaan baik fasilitasi maupun evaluasi ranperda yang dilakukan oleh 
Kemendagri/ Gubernur. Kewenangan pengawasan DPD terhadap pelakasanaan otonomi daerah juga dapat diwujudkan melalui fasilitasi penyelesaian permasalahan dalam pembentukan perda baik antara Pemerintah Daerah dengan Pemerintah Daerah maupun antara Pemerintah Daerah dengan Pemerintah Pusat dalam hal ini Kemendagri.

\section{Penutup}

Berdasarkan uraian diatas dapat disimpulkan bahwa kewenangan DPD dalam melakukan pemantauan dan evaluasi terhadap ranperda dan perda dapat berpotensi menghadirkan rivalitas kewenangan dengan Kemendagri/Gubernur, yang dapat berujung pada konflik antar Lembaga. Untuk itu relasi antara DPD dengan Pemerintah dalam hal ini Kemendagri/ Gubernur seharusnya, sebagai berikut:

1. Kewenangan DPD dalam pengawasan terhadap pelaksanaan otonomi daerah sebagaimana amanah UUDNRI Tahun 1945 seharusnya dilakukan dalam bentuk pengawasan terhadap aktifitas pelaksanaan kewenangan pembinaan baik fasilitasi maupun evaluasi ranperda yang dilakukan oleh Kemendagri/ Gubernur;

2. Kewenangan pengawasan DPD terhadap pelakasanaan otonomi daerah sebagaimana amanah UUDNRI Tahun 1945 juga dapat diwujudkan melalui fasilitasi penyelesaian permasalahan dalam pembentukan perda baik antara Pemerintah Daerah dengan Pemerintah Daerah maupun antara Pemerintah Daerah dengan Pemerintah Pusat dalam hal ini Kemendagri.

Untuk itu perlu dilakukan reformulasi kewenangan DPD dengan melakukan perubahan terhadap ketentuan dalam UU Nomor 2 Tahun 2018 yang memberikan kewenangan Pemantauan dan Evaluasi terhadap ranperda dan perda. 


\section{Daftar Pustaka}

Asshiddiqie, Jimly. Hukum Acara Pengujian Undang-Undang, Jakarta: Sinar Grafika. 2012.

Hartati, Menatap Masa Depan Dewan Perwakilan Daerah, Mitra Utama, Jambi. 2018.

Nurbaningsih, Enny. Problematika Pembentukan Peraturan Daerah (Aktualisasi Wewenang Mengatur dalam Era Otonomi Luas, Rajawali Press-Jakarta, 2019

Sihombing, Eka N.A.M dan Ali Marwan Hsb. Ilmu Perundang-undangan, Medan: Pustaka Prima

MPR RI, Panduan dalam Memasyarakatkan UUD Negara RI Tahun 1945, Jakarta: Sekretariat Jenderal Majelis Permusyawaratan Rakyat RI. 2003.

Sihombing, Eka NAM. "Perkembangan Kewenangan Pembatalan Peraturan Daerah dan Peraturan Kepala Daerah (Kajian Putusan Mahkamah Konstitusi Nomor 137/PUU-XIII/2015 dan Nomor 56/PUUXIV/2016)”, Jurnal Yudisial, 10 (2), 2017 : 217-234

Huda, Ni'matul. "Problematika yuridis di seputar pembatalan perda". Jurnal Konstitusi, 5(1), Juni 2008, 45- 62 


\section{Riwayat Penulis}

Eka NAM Sihombing, Lahir di Medan tanggal 11 November 1979, pendidikan S1 Ilmu Hukum pada Fakultas Hukum Universitas Sumatera Utara (selesai tahun 2003), kemudian melanjutkan pendidikan S2 pada Sekolah Pasca Sarjana Universitas Sumatera Utara Program Studi Ilmu Hukum (selesai tahun 2008), Mahasiswa Program S3 Ilmu Hukum Fakultas Hukum USU (2015-sekarang), Pendidikan lain yang pernah diikuti adalah Diklat Legal Drafter di Medan Tahun 2007, Diklat Penyusun dan Perancang Peraturan Perundang-undangan di Jakarta tahun 2009, Diklat Penguatan Perancang Peraturan PerundangUndangan di Jakarta Tahun 2013, Diklat ToT Perancang Peraturan PerundangUndangan di Jakarta Tahun 2015. Koordinator Perancang Peraturan PerundangUndangan pada Kanwil Kemenkumham Sumatera Utara. Ketua Majelis Pengawas Notaris Daerah Kota Sibolga dan Kabupaten Tapanuli Tengah 20142017, Ketua Majelis Pengawas Notaris Daerah Kota Sibolga, Kabupaten Tapanuli Tengah dan Kepulauan Nias 2017-2019, Ketua Majelis Pengawas Notaris Daerah Kota Binjai dan Kab. Langkat 2019- sekarang. Mengajar di Fakultas Hukum Universitas Muhammadiyah Sumatera Utara di Medan sejak 2008-sekarang. Pengurus Pusat Masyarakat Hukum Tata Negara Muhammadiyah/ MAHUTAMA (Divisi Regulasi dan Pemerintahan Daerah) masa jabatan 2018-2022. Anggota Asosiasi Filsafat Hukum Indonesia. Publikasi Buku : 1. Ilmu Perundang-Undangan bersama Ali Marwan (Pustaka Prima-Medan 2017), 2. Pembentukan Peraturan Daerah Partisipatif (Intelegensia-Malang, 2018), 3. Hukum Kelembagaan Negara (Ruas MediaYogyakarta, 2018), 4. Pengantar Hukum Konstitusi (Setara Press-Malang 2019), 5. Ilmu Negara Bersama Mirza Nasution (EnamMedia-Medan 2019), 6. Hukum Tata Negara Bersama Irwansyah (EnamMedia-Medan 2019). Menulis artikel di berbagai jurnal, diantaranya Jurnal Rechtsvinding, Jurnal De Jure, Jurnal Legislasi Indonesia, Jurnal Yudisial, dsb. Dapat dihubungi melalui e-mail: ekahombing@umsu.ac.id. 